\title{
Good Democratic Governance Can Combat COVID-19*
}

July 25, 2021

Susumu Annaka ${ }^{\dagger}$

\begin{abstract}
Some scholars argue that democracy is in crisis during the COVID-19 pandemic. However, successful cases such as New Zealand and Taiwan are often overlooked in these studies. These countries are often considered to have higher levels of government effectiveness. Using cross-national data from 148 countries, this study analyzed the impact of government effectiveness and its relationship with political regimes. The results revealed that democratic countries with higher government effectiveness can reduce COVID-19 cases and deaths. This study suggests that democratic countries need not give up freedom and need to improve government effectiveness to combat COVID-19.
\end{abstract}

* This work was supported by JSPS KAKENHI Grant Number JP20K22079. I thank Masaru Kohno and Munenori Kita for their helpful comments.

† Waseda Institute for Advanced Study, Japan, annaka@aoni.waseda.jp 


\section{Introduction}

Some scholars argue that democracy is in crisis during the COVID-19 pandemic. Some say that democratic countries face a trade-off between freedom and health (Alsan et al., 2020; Norheim et al., 2021; Thomson and Ip, 2020). Recent studies also reveal that democratic countries suffer from more COVID-19 deaths than authoritarian states (Cepaluni et al., 2020; Cheibub et al., 2020; Frey et al., 2020). However, some other studies object to these views, and the advantages in authoritarian countries are only superficial (Cassan and Steenvoort, 2020; Annaka, 2021; Badman et al., 2021).

Although this problem is a subject of heated debates, only a little attention is paid to a considerable variation of COVID-19 deaths among democratic countries. In Figure 1, the left-hand side graph plots the total number of COVID-19 deaths per 1 million (as of December 31, 2020) on the vertical axis, as reported by the John Hopkins University (2020), and the level of Polity2 in 2018 (latest) on the horizontal axis from the Polity V Project (Marshall et al., 2020). The population data were obtained from World Bank. The latter codes democracy levels from -10 (most autocratic) to 10 (most democratic). The correlation coefficient between the two variables is $0.3885(p<0.001)$. Using an alternative measure of political regimes makes the relationship more apparent. The right-hand side graph illustrates the relationship by using the multiplicative 
polyarchy index (MPI) in 2019 (latest) from the Varieties of Democracy (V-Dem) Project (Coppedge et al., 2020). The latter codes democracy levels from low to high (0-1) (Coppedge et al., 2020). The correlation coefficient between these two variables is 0.4823 $(p<0.001)$. These moderate, positive relationships appear to support the argument that democratic governments are disadvantaged in coping with the current pandemic, at least nominally.
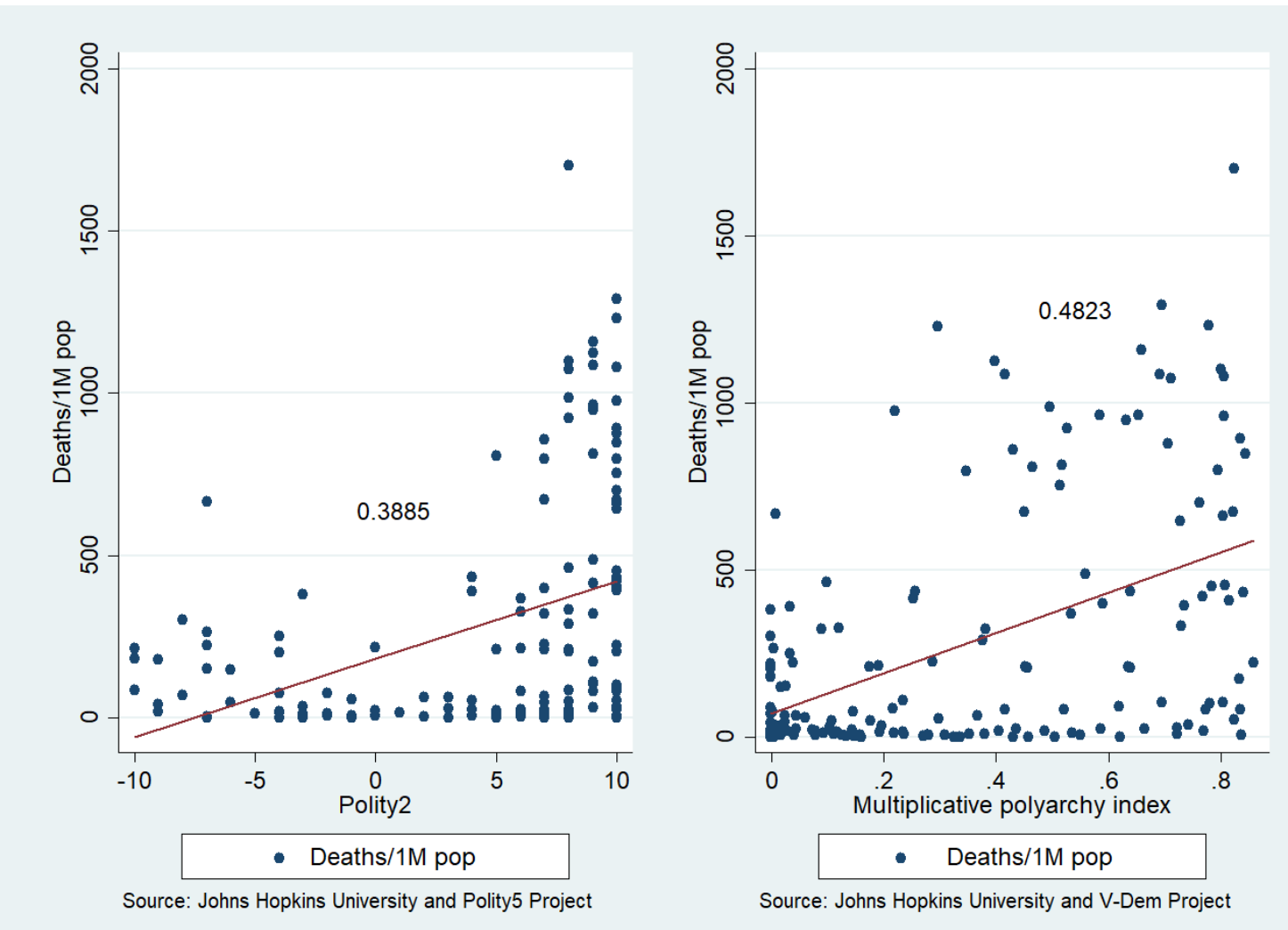

Figure 1: Relationship between Polity2 and MPI and number of COVID-19 deaths 
However, there is a significant variance in democratic countries. Several democratic countries are under 500 deaths per 1 million population, and many of them have over 500 deaths. Even in democracies, countries such as Taiwan and New Zealand seem to be relatively successful in combating COVID-19 by the end of 2020. These countries are islands, but the United Kingdom, which has suffered severely from the pandemic, is also an island. Once the virus invades a country, it cannot usually combat the pandemic simply by taking advantage of being an island.

Taiwan and New Zealand are being praised for their governing and bureaucratic capability. Previous research has reported that government effectiveness is negatively correlated with COVID-19 deaths (Liang et al., 2020; Serikbayeva et al., 2020). Combating COVID-19 requires a tremendous amount of information related to the issue. Government effectiveness varies among nations; democratic countries tend to have more effective governments. However, this is not always the case; the correlation coefficient between Polity 2 and government effectiveness, obtained from the World Bank, is only 0.3796. We find inefficient governments among democracies and efficient governments among authoritarian states. Then, we cannot straightforwardly conclude that "democracy suffers." As the cases of Taiwan and New Zealand show, democratic governments with higher government effectiveness can combat COVID-19. 
In addition, a study shows that democratic countries with a higher quality of government tend to have fewer people affected by natural disasters (Persson and Povitkina, 2017). The current situation of the pandemic is like a natural disaster. We can naturally expect that the same is true for this pandemic. Then this study analyzes the interaction effects of democracy and government effectiveness on COVID-19. It argues that democracy is not a determinant of the higher number of COVID-19 deaths but conditions the effects of government effectiveness on fatalities. This suggests that effective democratic governments can reduce COVID-19 cases and deaths.

\section{Analysis}

\subsection{Model}

Using cross-sectional data, this section analyzes the interaction effect between political regimes and government effectiveness on COVID-19 deaths. It estimates the following specifications:

$$
\begin{aligned}
\text { COVID death }_{i} & =\alpha+\beta_{1} \text { Political Regimes }_{i} \\
& +\beta_{2} \text { Governance }_{i}+\beta_{3} \text { Political Regimes }_{i} \\
& \left.\times \text { Governance }_{i}\right)+\beta^{\prime}{ }_{4} X_{i}+\varepsilon_{i}
\end{aligned}
$$


COVID death is the total number of COVID-19 deaths (as of December 31, 2020). Political Regimes indicates Polity2 Score or MPI, and Governance represents government effectiveness. $X$ is a vector of controls. $\varepsilon$ is an error term. $i$ represents each country.

The total number of deaths is obtained from the John Hopkins University. Daily data available elsewhere cannot be utilized because almost all other necessary covariates, such as GDP per capita, are yearly data. This study constructs cross-national data on 148 countries, obtaining political regime variables from the Polity Project and V-Dem Project. Government effectiveness, GDP per capita, total population, population density, and population ratio age 65 and above are taken from the World Bank. The latest available yearly data (2019) for all variables are used (except for population density (2018)). Government effectiveness attempts to capture "perceptions of the quality of public services, the quality of the civil service and the degree of its independence from political pressures, the quality of policy formulation and implementation, and the credibility of the government's commitment to such policies.” (Kaufmann et al. 2010: 223). It is already employed by the studies which analyzed the relationship between state capacity and Covid-19 (Liang et al., 2020; Serikbayeva et al., 2020). The estimation model includes both the latitude and longitude obtained from John Hopkins University, which captures 
geographic characteristics, such as humidity and cultural factors, such as high awareness of mask usage and preventive behavior affecting the severity of COVID-19 deaths as well as any remaining regionally specific effects. Finally, the model includes the days since the first confirmed case to capture the linear trends of the infection.

For estimation, negative binomial regression with robust standard errors and log transformation of the dependent variables for ordinary least squares (OLS) (Appendix 1 and 2) are applied, considering the skewed distribution of the dependent variable. The control variables (except for latitude, longitude, and days since the first confirmed case) are logged due to their skewed distributions. Model goodness of fit was assessed using the Akaike information criterion (AIC) and the Bayesian information criterion (BIC) based on Lindsey (2014) and Gluzmann et al. (2015). However, note that the key variables, such as the political regime variables, are included in the estimations, regardless of AIC and BIC assessment. Descriptive statistics are provided in Appendix 1.

First, the analyses do not include positive cases as a control because these are strongly correlated with deaths; positive cases must precede all deaths. The correlation coefficient is $0.8128(p<0.001)$. If positive cases are included in the estimations, these capture most of the effects of other variables on deaths. After running the regression 
without the positive case variable, it is included as a control. This difference can tell us what effects the included independent variables may have.

\subsection{Results}

The results of the negative binomial regression without positive cases as a control are reported in Table 1. Models 1 and 2 analyze the relationship between Polity2 and deaths, and Models 3 and 4 analyze that between MPI and deaths. Models 2 and 4 include the interaction terms between political regime variables and government effectiveness. These models reveal that the political regime itself consistently does not matter in terms of COVID-19 deaths. On the other hand, GDP per capita is consistently positive and statistically significant. Models 1 and 3 indicate that government effectiveness is negatively correlated with the number of deaths and is statistically significant without the interaction terms. Models 2 and 4 report that the interaction terms are negatively associated with the number of deaths and are statistically significant.

Figure 4 illustrates the marginal effects of government effectiveness on the number of deaths conditioned by the level of political regime variables based on Models 2 and 4 . These graphs show the downward trends of the dependent variable as the level of political regime variables is higher, although the line is almost flat after reaching some 
level of democracy. They also reveal that all statistically significant plots are under zero on the Y-axis. These results indicate that effective democratic governments tend to have fewer COVID-19 deaths.

Table 1: Determinants of COVID-19 Deaths (Negative Binomial Regression)

\begin{tabular}{|c|c|c|c|c|}
\hline & (1) & (2) & (3) & (4) \\
\hline & NB & NB & NB & NB \\
\hline VARIABLES & Death cases & Death cases & Death cases & Death cases \\
\hline \multirow[t]{2}{*}{ Polity 2} & -0.00143 & -0.0169 & & \\
\hline & $(0.0244)$ & $(0.0254)$ & & \\
\hline \multirow[t]{2}{*}{ MPI } & & & -0.997 & -0.303 \\
\hline & & & $(0.659)$ & $(0.747)$ \\
\hline \multirow[t]{2}{*}{ Government Effectiveness } & $-0.533 * *$ & -0.248 & $-0.407 *$ & -0.0240 \\
\hline & $(0.237)$ & $(0.261)$ & $(0.235)$ & $(0.249)$ \\
\hline \multirow[t]{2}{*}{ Polity $2 \times$ Government Effectiveness } & & $-0.0602 * *$ & & \\
\hline & & $(0.0245)$ & & \\
\hline \multirow[t]{2}{*}{ MPI $\times$ Government Effectiveness } & & & & $-1.370 * * *$ \\
\hline & & & & $(0.367)$ \\
\hline \multirow[t]{2}{*}{ GDP per capita $(\log )$} & $0.649 * * *$ & $0.635 * * *$ & $0.621 * * *$ & $0.711 * * *$ \\
\hline & $(0.161)$ & $(0.148)$ & $(0.139)$ & $(0.135)$ \\
\hline \multirow[t]{2}{*}{ Total Population (log) } & $1.069 * * *$ & $1.074 * * *$ & $1.055^{* * *}$ & $1.079 * * *$ \\
\hline & $(0.0771)$ & $(0.0801)$ & $(0.0763)$ & $(0.0785)$ \\
\hline \multirow[t]{2}{*}{ Population Density (log) } & -0.0267 & -0.0176 & -0.0187 & -0.0328 \\
\hline & $(0.0843)$ & $(0.0795)$ & $(0.0862)$ & $(0.0807)$ \\
\hline \multirow[t]{2}{*}{ Age 65 and above (ratio) } & $0.717 * * *$ & $0.974 * * *$ & $0.952 * * *$ & $0.899 * * *$ \\
\hline & $(0.236)$ & $(0.267)$ & $(0.216)$ & $(0.231)$ \\
\hline \multirow[t]{2}{*}{ Latitude } & $0.0124 * *$ & $0.0103 *$ & 0.00969 & $0.0132 * *$ \\
\hline & $(0.00596)$ & $(0.00592)$ & $(0.00608)$ & $(0.00582)$ \\
\hline \multirow[t]{2}{*}{ Longitude } & $-0.0122 * * *$ & $-0.0117 * * *$ & $-0.0133 * * *$ & $-0.0119 * * *$ \\
\hline & $(0.00232)$ & $(0.00230)$ & $(0.00248)$ & $(0.00233)$ \\
\hline Days since the first confirmed case & 0.00539 & 0.00340 & 0.00544 & 0.00248 \\
\hline
\end{tabular}




\begin{tabular}{lcccc} 
& $(0.00713)$ & $(0.00718)$ & $(0.00712)$ & $(0.00719)$ \\
Constant & $-18.44 * * *$ & $-18.15 * * *$ & $-18.05 * * *$ & $-18.28 * * *$ \\
& $(2.134)$ & $(2.102)$ & $(2.112)$ & $(2.082)$ \\
\hline AIC & 2535.293 & 2531.343 & 2552.234 & 2543.688 \\
BIC & 2568.187 & 2567.228 & 2585.203 & 2579.655 \\
\hline Observations & 147 & 147 & 148 & 148 \\
\hline
\end{tabular}

Robust standard errors in parentheses

$* * * \mathrm{p}<0.01, * * \mathrm{p}<0.05, * \mathrm{p}<0.1$
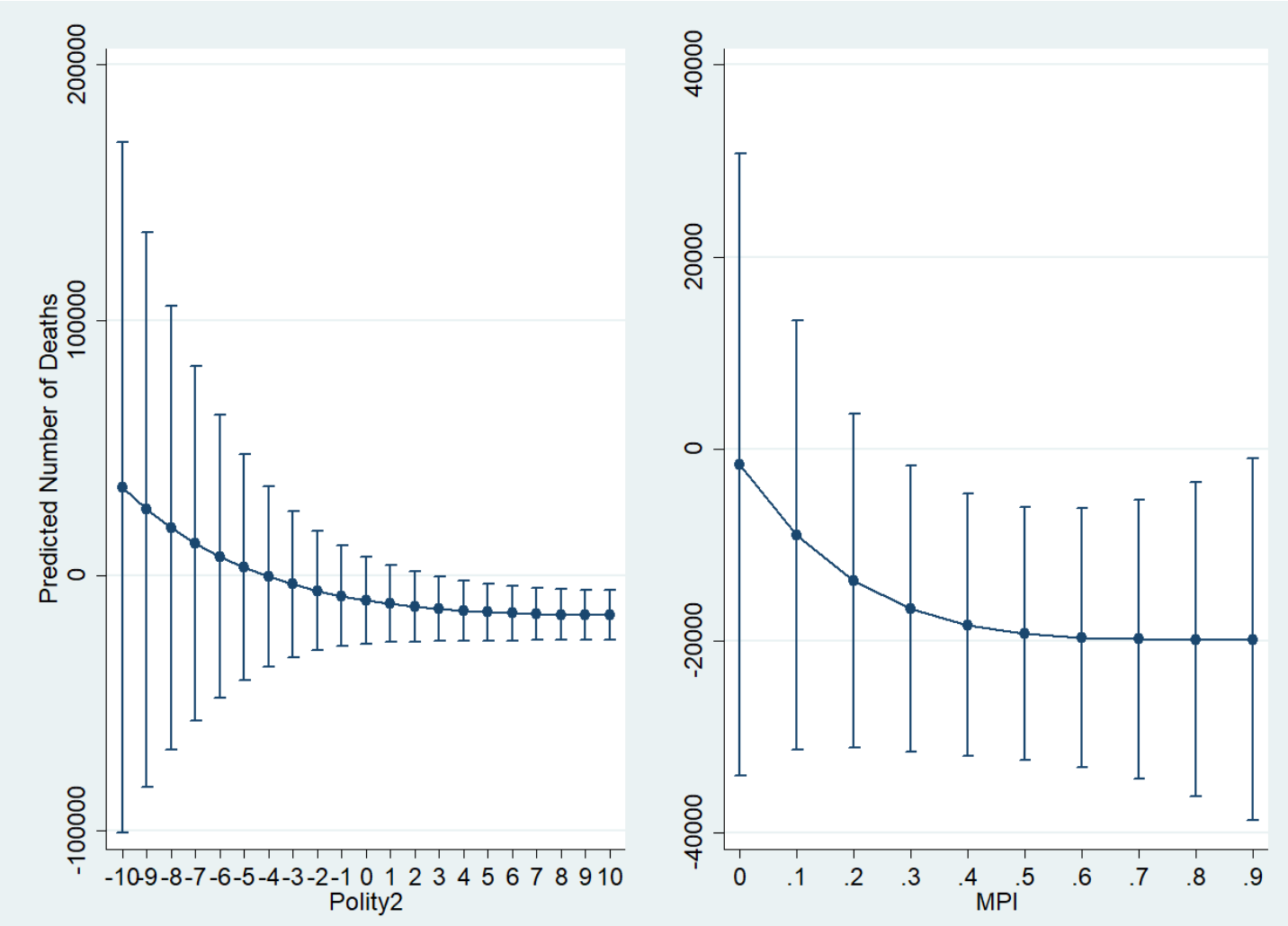

Figure 4: Average Marginal Effects of Government Effectiveness on Deaths (95\% CIs)

Table 2 shows that the political regime variables in Models 5 to 8 are not statistically significant. However, after controlling for positive cases, the coefficients of 
some variables drastically change. For example, GDP per capita in all these models is no longer significant. This should mean that positive cases capture the prevalence of the disease. Prosperous countries are likely to have a higher number of positive cases, but, naturally, prosperity does not matter in terms of deaths after controlling for these positive cases. In addition, it is also quite natural that after controlling for these positive cases, the sign of interaction term coefficients between political regime variables and government effectiveness in Models 6 and 8 is positive because the effect of the latter should be captured as a reducing one on positive cases.

This relationship is illustrated in Figure 5. Both graphs show the marginal effects of government effectiveness on the number of deaths conditioned by the level of political regime variables based on Models 6 and 8, respectively. The plots in both graphs are upward. Nevertheless, all predicted values are significantly below zero. This implies a considerable reduction in the impact of government effectiveness on COVID-19 deaths. 
Table 2: Determinants of COVID-19 Deaths with Positive Cases as a Control

\begin{tabular}{|c|c|c|c|c|}
\hline & $(5)$ & (6) & (7) & (8) \\
\hline & NB & NB & NB & NB \\
\hline VARIABLES & Death cases & Death cases & Death cases & Death cases \\
\hline \multirow[t]{2}{*}{ Polity2 } & 0.00660 & 0.00869 & & \\
\hline & $(0.0120)$ & $(0.0113)$ & & \\
\hline \multirow[t]{2}{*}{ MPI } & & & $0.596 *$ & 0.361 \\
\hline & & & $(0.312)$ & $(0.309)$ \\
\hline \multirow[t]{2}{*}{ Government Effectiveness } & $-0.474 * * *$ & $-0.590 * * *$ & $-0.571 * * *$ & $-0.679 * * *$ \\
\hline & $(0.155)$ & $(0.172)$ & $(0.158)$ & $(0.193)$ \\
\hline \multirow[t]{2}{*}{ Polity $2 \times$ Government Effectiveness } & & $0.0302 * *$ & & \\
\hline & & $(0.0129)$ & & \\
\hline \multirow[t]{2}{*}{ MPI $\times$ Government Effectiveness } & & & & $0.425^{*}$ \\
\hline & & & & $(0.247)$ \\
\hline \multirow[t]{2}{*}{ GDP per capita (log) } & 0.127 & 0.0967 & 0.118 & 0.0687 \\
\hline & $(0.110)$ & $(0.0994)$ & $(0.103)$ & $(0.0873)$ \\
\hline \multirow[t]{2}{*}{ Total Population (log) } & $0.314 * * *$ & $0.288 * * *$ & $0.305 * * *$ & $0.271 * * *$ \\
\hline & $(0.0639)$ & $(0.0571)$ & $(0.0632)$ & $(0.0562)$ \\
\hline \multirow[t]{2}{*}{ Population Density (log) } & -0.0700 & -0.0598 & $-0.0710 *$ & -0.0629 \\
\hline & $(0.0431)$ & $(0.0407)$ & $(0.0420)$ & $(0.0415)$ \\
\hline \multirow[t]{2}{*}{ Age 65 and above (ratio) } & $0.475 * * *$ & $0.366^{* * *}$ & $0.404 * * *$ & $0.405 * * *$ \\
\hline & $(0.114)$ & $(0.120)$ & $(0.107)$ & $(0.106)$ \\
\hline \multirow[t]{2}{*}{ Latitude } & 0.00122 & 0.000817 & 0.00190 & 0.000485 \\
\hline & $(0.00278)$ & $(0.00250)$ & $(0.00279)$ & $(0.00260)$ \\
\hline \multirow[t]{2}{*}{ Longitude } & $-0.00413 * * *$ & $-0.00428 * * *$ & $-0.00335^{* * *}$ & $-0.00371 * * *$ \\
\hline & $(0.000946)$ & $(0.000910)$ & $(0.000970)$ & $(0.000978)$ \\
\hline \multirow[t]{2}{*}{ Days since the first confirmed case } & -0.00521 & -0.00319 & -0.00445 & -0.00283 \\
\hline & $(0.00548)$ & $(0.00483)$ & $(0.00535)$ & $(0.00481)$ \\
\hline \multirow[t]{2}{*}{ Confirmed Cases (log) } & $0.882 * * *$ & $0.908 * * *$ & $0.897 * * *$ & $0.925 * * *$ \\
\hline & $(0.0428)$ & $(0.0386)$ & $(0.0406)$ & $(0.0372)$ \\
\hline \multirow[t]{2}{*}{ Constant } & $-7.911 * * *$ & $-8.043 * * *$ & $-8.162 * * *$ & $-7.984 * * *$ \\
\hline & (1.264) & $(1.229)$ & (1.216) & $(1.200)$ \\
\hline AIC & 2310.704 & 2305.24 & 2324.679 & 2322.122 \\
\hline $\mathrm{BIC}$ & 2346.59 & 2344.116 & 2360.645 & 2361.086 \\
\hline Observations & 147 & 147 & 148 & 148 \\
\hline
\end{tabular}


Robust standard errors in parentheses

$* * * \mathrm{p}<0.01, * * \mathrm{p}<0.05, * \mathrm{p}<0.1$
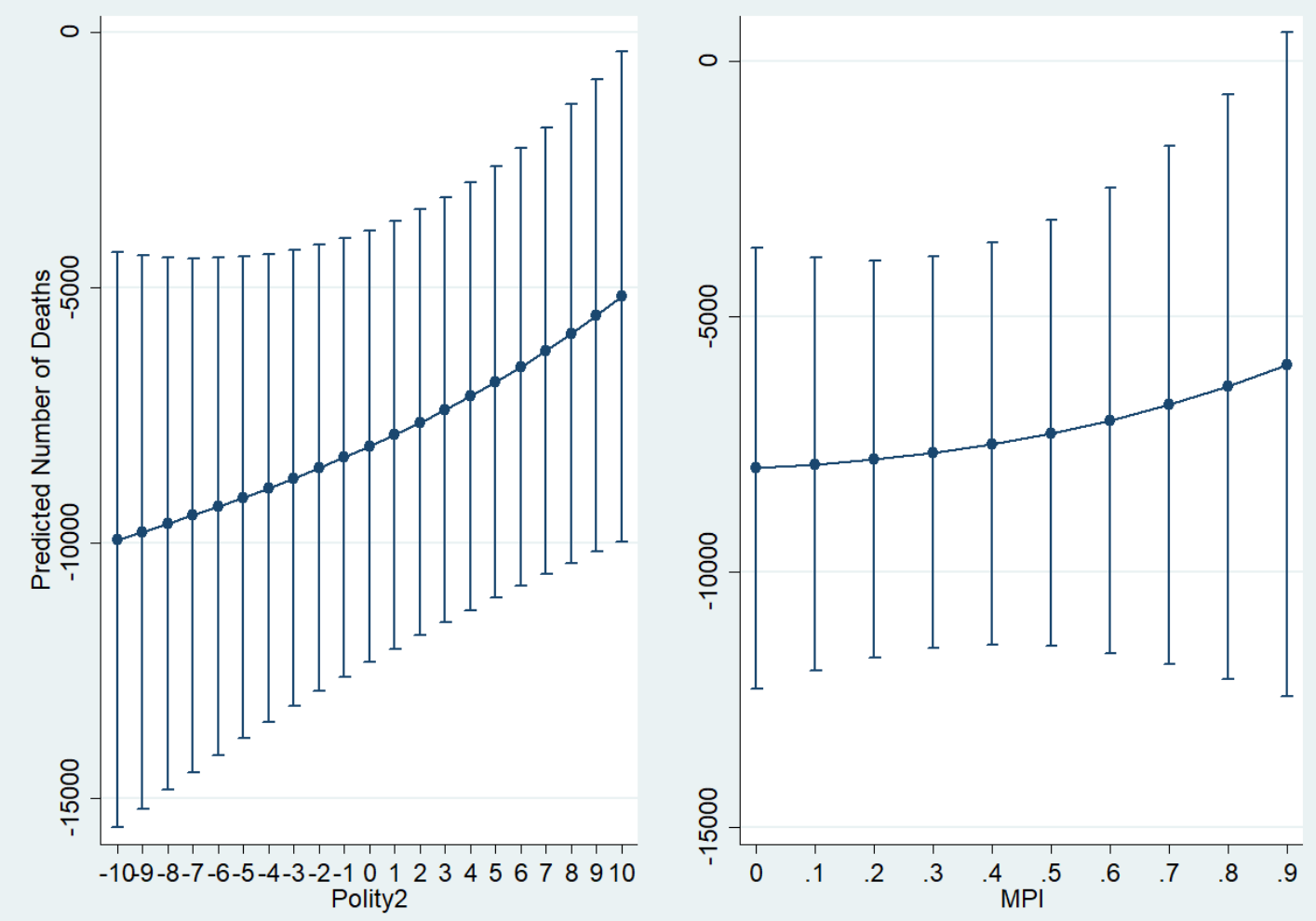

Figure 5: Average Marginal Effects of Government Effectiveness on Deaths with

Positive Cases as a Control (95\% CIs)

The analysis of positive cases of COVID-19 is reported in Table 3. Except for

Model 11, the political regime variables are not statistically significant. The MPI in Model

11 is statistically significant, but the sign of the coefficient is negative. Government

effectiveness in Models 9 and 11 is not statistically significant. However, the interaction 
terms in Models 10 and 12 are statistically significant and negative, as expected. GDP per capita in Models 9 to 12 is robustly significant, as expected.

The marginal effects of government effectiveness on the number of positive cases conditioned by the level of political regime variables based on Models 10 and 12, respectively, are illustrated in Figure 6 . The plots in both graphs show the downward trends of the dependent variable as the level of political regime variables is higher, although the line is almost flat after reaching some level of democracy. However, almost all predicted values are below zero. The effect is significant, even though the interaction term between Polity2 and government effectiveness appears to be relatively small.

The above results consistently show that the political regime variables are not statistically significant. On the other hand, democratic countries with good governance can reduce COVID-19 cases and deaths. GDP per capita is directly correlated with cases and indirectly correlated with fatalities. Almost all the OLS results in Appendixes 2 and 3 are identical to those above. 
Table 3: Determinants of COVID-19 Positive Cases

\begin{tabular}{|c|c|c|c|c|}
\hline & (9) & $(10)$ & $(11)$ & (12) \\
\hline & NB & NB & NB & NB \\
\hline VARIABLES & Confirmed Cases & Confirmed Cases & Confirmed Cases & Confirmed Cases \\
\hline \multirow[t]{2}{*}{ Polity 2} & -0.00310 & -0.0220 & & \\
\hline & $(0.0206)$ & $(0.0213)$ & & \\
\hline \multirow[t]{2}{*}{ MPI } & & & $-1.238 * *$ & -0.327 \\
\hline & & & $(0.586)$ & $(0.665)$ \\
\hline \multirow[t]{2}{*}{ Government Effectiveness } & -0.276 & 0.184 & -0.108 & $0.423 *$ \\
\hline & $(0.217)$ & $(0.229)$ & $(0.228)$ & $(0.233)$ \\
\hline \multirow[t]{2}{*}{ Polity $2 \times$ Government Effectiveness } & & $-0.0935 * * *$ & & \\
\hline & & $(0.0200)$ & & \\
\hline \multirow[t]{2}{*}{ MPI $\times$ Government Effectiveness } & & & & $-1.825 * * *$ \\
\hline & & & & $(0.327)$ \\
\hline \multirow[t]{2}{*}{ GDP per capita $(\log )$} & $0.699 * * *$ & $0.681 * * *$ & $0.656 * * *$ & $0.761 * * *$ \\
\hline & $(0.151)$ & $(0.135)$ & $(0.132)$ & $(0.119)$ \\
\hline \multirow[t]{2}{*}{ Total Population (log) } & $0.912 * * *$ & $0.933 * * *$ & $0.885 * * *$ & $0.930 * * *$ \\
\hline & $(0.0714)$ & $(0.0712)$ & $(0.0739)$ & $(0.0691)$ \\
\hline \multirow[t]{2}{*}{ Population Density (log) } & 0.0545 & 0.0506 & 0.0544 & 0.0283 \\
\hline & $(0.0718)$ & $(0.0682)$ & $(0.0756)$ & $(0.0696)$ \\
\hline \multirow[t]{2}{*}{ Age 65 and above (ratio) } & 0.318 & $0.680 * * *$ & $0.571 * * *$ & $0.521 * *$ \\
\hline & $(0.212)$ & $(0.232)$ & $(0.198)$ & $(0.203)$ \\
\hline \multirow[t]{2}{*}{ Latitude } & $0.0139 * *$ & $0.0118 * *$ & $0.0101 *$ & $0.0158 * * *$ \\
\hline & $(0.00562)$ & $(0.00540)$ & $(0.00589)$ & $(0.00527)$ \\
\hline \multirow[t]{2}{*}{ Longitude } & $-0.00882 * * *$ & $-0.00816 * * *$ & $-0.0103 * * *$ & $-0.00886 * * *$ \\
\hline & $(0.00257)$ & $(0.00248)$ & $(0.00273)$ & $(0.00235)$ \\
\hline \multirow[t]{2}{*}{ Days since the first confirmed case } & 0.00822 & 0.00232 & 0.00922 & 0.00328 \\
\hline & $(0.00652)$ & $(0.00630)$ & $(0.00710)$ & $(0.00655)$ \\
\hline \multirow[t]{2}{*}{ Constant } & $-12.75 * * *$ & $-11.59 * * *$ & $-12.20 * * *$ & $-12.03 * * *$ \\
\hline & $(2.040)$ & $(1.931)$ & $(2.100)$ & (1.916) \\
\hline AIC & 3738.707 & 3724.254 & 3759.499 & 3740.976 \\
\hline $\mathrm{BIC}$ & 3771.602 & 3760.14 & 3792.468 & 3776.943 \\
\hline Observations & 147 & 147 & 148 & 148 \\
\hline
\end{tabular}

Robust standard errors in parentheses

$* * * \mathrm{p}<0.01, * * \mathrm{p}<0.05, * \mathrm{p}<0.1$ 

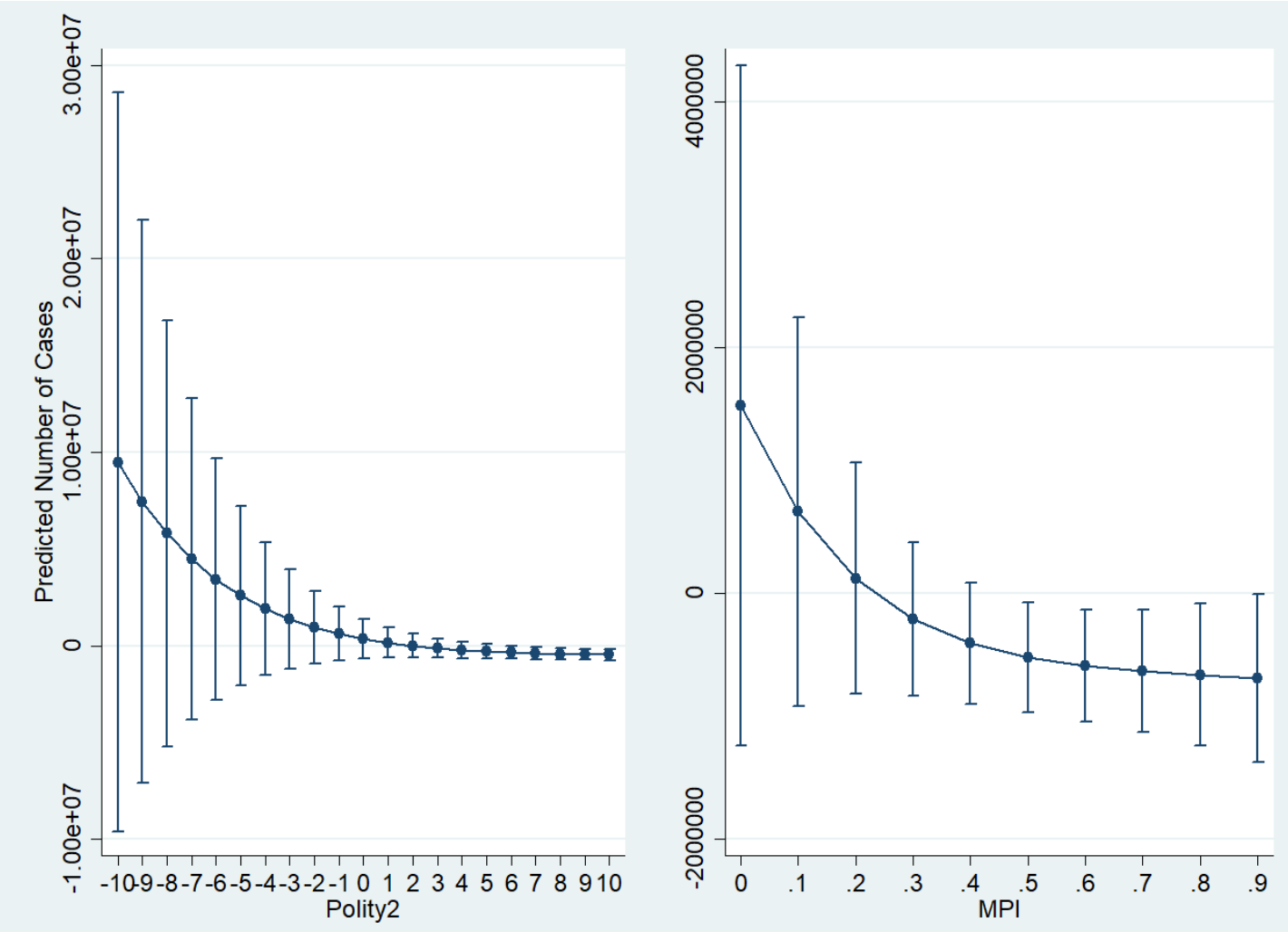

Figure 6: Average Marginal Effects of Government Effectiveness on Cases (95\% CIs)

\section{Discussion}

The current study demonstrates that government effectiveness is an essential factor in reducing COVID-19 cases and deaths. This result strongly supports the findings of Liang et al. (2020) and Serikbayeva et al. (2020). However, the former does not consider the effect of political regimes. The latter uses the Freedom House score only to define democracy, not paying attention to the interaction effects of democracy and government 
effectiveness on Covid-19. On the other hand, this study analyzes the interaction effects using the Polity Project and V-Dem Project data and reports that good democratic governance can significantly reduce COVID-19 cases and deaths. These results truly contribute to the literature.

Also, the aforementioned results refute the arguments for the advantages of authoritarian countries (Cepaluni et al., 2020; Cheibub et al., 2020; Frey et al., 2020). Even though the above analyses are based on reported data susceptible to manipulation, which seems advantageous for authoritarian countries (Adiguzel et al., 2020; Kapoor et al., 2020; Annaka, 2021; Badman et al. 2021), this study does not find the advantage of authoritarian countries after controlling for other factors that may affect COVID-19 cases and deaths.

\section{Conclusion}

Scholars have argued that democracy is in crisis during the COVID-19 pandemic. Some say that democratic countries face a trade-off between freedom and health. Recent studies have also revealed that democratic countries suffer from more COVID-19 deaths than authoritarian states. However, these studies often overlook successful cases such as New Zealand and Taiwan. These countries are often considered to have higher levels of 
government effectiveness. This study analyzed the impact of government effectiveness and its relationship with political regimes. The results revealed that democratic countries with higher government effectiveness can reduce COVID-19 cases and deaths. In addition, political regimes are not correlated with COVID-19 cases and deaths at the conventional level after controlling for other factors. This study suggests that democratic countries do not need to reduce social freedoms and needs to improve government effectiveness to combat COVID-19.

\section{References}

Adiguzel, F.S., Cansunar, A., Corekcioglu, G., 2020. Truth or dare? Detecting syste matic manipulation of COVID-19 statistics. J. Pol. Inst. Pol. Econ. 1, 543-5 57.

Alsan, M., Braghieri, L., Eichmeyer, S., Kim, M.J., Stantcheva, S., Yang, D.Y., 202

0. Civil Liberties in Times of Crisis National Bureau of Economic Researc h. working paper series No. 27972.

Annaka, S., 2021. Political Regime, Data Transparency, and COVID-19 Deaths. SS M - Population Health, 15, 100832. 
Badman, R. P., Wu, Y., Inukai, K., and Akaishi, R. 2021. Blessing or Curse of De mocracy?: Current Evidence from the Covid-19 Pandemic, arXiv:2105.1086 5.

Cassan, G., Steenvoort, M.V., 2020. Political Regime and COVID 19 Death Rate: E fficient, Biasing or Simply Different Autocracies? Available online: arXiv:2 $\underline{101.09960 .}$.

Cepaluni, G., Dorsch, M., Branyiczki, R., 2020. Political regimes and deaths in the early stages of the COVID-19 pandemic. Available at SSRN. Available onli ne: https://ssrn.com/abstract=3586767 or http://dx.doi.org/10.2139/ssrn.35867 67 (Accessed 2020.9.11) (Accessed April 27, 2020).

Cheibub, J.A., Hong, J.Y.J., Przeworski, A., 2020. Rights and deaths: Government r eactions to the pandemic. Available at SSRN. Available online: https://ssrn.c om/abstract=3645410 or http://dx.doi.org/10.2139/ssrn.3645410 (Accessed Ju ly 7,2020$)$.

Coppedge, M., Gerring, J., Knutsen, C.H., Lindberg, S.I., Teorell, J., Altman, D., B ernhard, M., Fish, M.S., Glynn, A., Hicken, A., Luhrmann, A., Marquardt, K. L., McMann, K., Paxton, P., Pemstein, D., Seim, B., Sigman, R., Skaani ng, S., Staton, J., Wilson, S., Cornell, A., Alizada, N., Gastaldi, L., Gjerlø 
w, H., Hindle, G., Ilchenko, N., Maxwell, L., Mechkova, V., Medzihorsky,

J., Römer, J., Sundström, A., Tzelgov, E., Wang, Y., Wig, T., and Ziblatt, D., 2020. V-Dem [Country-Year/Country-Date] Dataset v10. Varieties of De mocracy (V-Dem) Project. https://doi.org/10.23696/vdemds20.

Frey, C.B., Presidente, G., Chen, C., 2020. Democracy, Culture, and Contagion: Pol itical Regimes and Countries Responsiveness to Covid-19, Covid Economic s. 18 .

Gerring, J., Knutsen, C.H., Maguire, M., Skaaning, S., Teorell, J., Coppedge, M., 2 021. Democracy and human development: Issues of conceptualization and measurement. Democratization 28, 308-332. DOI: 10.1080/13510347.2020.1 $\underline{818721 .}$.

Gluzmann, P., Panigo, D., 2015. Global search regression: A new automatic modelselection technique for cross-section, time-series, and panel-data regressions. The Stata Journal 15, 325-349. doi:10.1177/1536867X1501500201. Johns Hopkins University, 2020. COVID 19 data repository. Center for Systems Sci ence and Engineering (CSSE), Available online: https://github.com/CSSEGIS andData/COVID19 (Accessed August 8, 2020). 
Kapoor, M., Malani, A., Ravi, S., Agrawal, A., 2020. Authoritarian governments ap pear to manipulate COVID data. Available online: https://arxiv.org/abs/2007. 09566 (Accessed 2020.9.11), Ar.Xiv.

Kaufmann, D., Kraay, A., Mastruzzi, M. 2011. The Worldwide Governance Indicato rs: Methodology and Analytical Issues. Hague Journal on the Rule of Law. 3: $220-246$.

Liang, L.L., Tseng, C.H., Ho, H.J., Wu, C.Y., 2020. Covid-19 mortality is negativel $\mathrm{y}$ associated with test number and government effectiveness. Science Repor t. Sci. Rep. 10, 12567. https://doi.org/10.1038/s41598-020-68862-x.

Lindsey, C., 2014. VSELECT: Stata Module to Perform Linear Regression Variable Selection, Statistical Software Components S457808, Boston College Depart ment of Economics, Revised December 15, 2014.

Marshall, M.G., Jaggers, K., Gurr, T.R., 2020. Polity V project, political regime cha racteristics and transitions. Available online: http://www.systemicpeace.org/i nscrdata.html (Accessed August 8, 2020). Center for Systemic Peace.

Norheim, O.F., Abi-Rached, J.M., Bright, L.K., Bærøe, K., Ferraz, O.L.M., Gloppen, S., Voorhoeve, A., 2021. Difficult trade-offs in response to COVID-19: Th 
e case for open and inclusive decision making. Nat. Med. 27, 10-13. https:/ /doi.org/10.1038/s41591-020-01204-6.

Persson, T.A., Povitkina, M. 2017. "Gimme Shelter": The Role of Democracy and I nstitutional Quality in Disaster Preparedness. Political Research Quarterly. 7 0(4):833-847. doi:10.1177/1065912917716335

Serikbayeva, B., Abdulla, K., Oskenbayev, Y., 2020. State capacity in responding to COVID-19. Int. J. Public Admin., 1-11.

Thomson, S., Ip, E.C., 2020. COVID-19 emergency measures and the impending au thoritarian pandemic. J. Law Biosci. 7, 1saa064. doi:10.1093/jlb/1saa064.

Wang, Y., Mechkova, V., Andersson, F., 2019. Does democracy enhance health? Ne w empirical evidence 1900-2012. Pol. Res. Q. 72, 554-569.

World Development Indicators, 2020. Available online: http://datatopics.worldbank.or g/world development indicators/ (accessed on August 8, 2020). 
Appendix 1: Descriptive Statistics

\begin{tabular}{lrrrrr}
\hline \multicolumn{1}{c}{ Variable } & Obs & Mean & Std. Dev. & Min & Max \\
\hline Confirmed Deaths & 148 & 12220.11 & 38128.79 & 0 & 351932 \\
Confirmed Deaths per 1M pop (log) & 144 & 4.4333 & 2.1006 & -1.7519 & 7.4386 \\
Confirmed Cases & 148 & 558188.3 & 1989659 & 41 & $2.01 \mathrm{E}+07$ \\
Confirmed Cases 1M pop (log) & 148 & 8.4152 & 2.1657 & 1.7437 & 11.2236 \\
Polity2 & 147 & 4.5306 & 5.9695 & -10 & 10 \\
MPI & 148 & 0.3614 & 0.2976 & 0 & 0.8580 \\
Government Effectiveness & 148 & -0.0054 & 0.9753 & -2.2794 & 2.2211 \\
GDP per capita (log) & 148 & 8.6499 & 1.4774 & 5.3379 & 11.6179 \\
Total Population (log) & 148 & 16.3822 & 1.5224 & 13.2176 & 21.0581 \\
Population Density (log) & 148 & 4.2510 & 1.3679 & 0.7109 & 8.9813 \\
Age 65 and above Ratio (log) & 148 & 1.9301 & 0.7788 & 0.1454 & 3.3323 \\
Latitude & 148 & 19.5041 & 25.3300 & -40.9006 & 61.9241 \\
Longitude & 148 & 21.9166 & 57.9347 & -102.5528 & 178.0650 \\
Days since First Confirmed Case & 148 & 304.3041 & 20.4153 & 233 & 345 \\
\hline
\end{tabular}


Appendix 2: Determinants of COVID-19 Deaths (OLS) 


\section{(1)}

(2)

(3)

(4)

(5)

(6)

(7)

(8)

OLS

OLS

OLS

OLS

OLS

OLS

OLS

OLS

Death per Death per Death per Death per Death per Death per Death per Death per

\begin{tabular}{lll} 
VARIABLES & $1 \mathrm{M}(\log )$ & $1 \mathrm{M}(\log )$ \\
\hline Polity2 & 0.00969 & 0.00708 \\
& $(0.0339)$ & $(0.0351)$
\end{tabular}

MPI

$\begin{array}{ll}-0.453 & 0.0805 \\ (0.759) & (0.886)\end{array}$

0.334

0.134

(0.449)

(0.471)

Government

Effectiveness

$\begin{array}{cccccccc}-0.825 * * * & -0.671 * * & -0.743 * * * & -0.431 & -0.461 * * * & -0.599 * * * & -0.521 * * * & -0.643 * * * \\ (0.247) & (0.281) & (0.273) & (0.309) & (0.147) & (0.186) & (0.165) & (0.216)\end{array}$

Polity $2 \times$

Government

Effectiveness

$-0.0309$

0.0295

(0.0264)

(0.0181)

MPI $\times$

Government

Effectiveness

$$
\begin{gathered}
-1.021 * * \\
(0.496)
\end{gathered}
$$

GDP per

capita $(\log )$

$$
0.890 * * *
$$

$0.880 * * *$

$0.865 * * *$

$0.889^{* * *}$

0.0189

0.00516

0.0175

$-0.0160$

(0.174)

(0.172)

(0.161)

(0.153)

(0.102)

(0.102)

(0.0953)

(0.102)

Population

Density (log)

$$
0.0109
$$

$\begin{array}{ll}-0.00649 & 0.00133\end{array}$

$-0.0197$

$-0.0599$

$$
-0.0452
$$

$-0.0567$

$-0.0496$

(0.105)

(0.110)

(0.104)

(0.112)

(0.0672)

(0.0632)

(0.0670)

$(0.0661)$

Age 65 and

above (ratio)

$0.697 * *$

$0.794 * *$

$0.860 * * *$

$0.854 * * *$

$0.570 * * *$

$0.475^{* * *}$

$0.529 * * *$

$0.522 * * *$

(0.310)

(0.324)

(0.269)

(0.270)

(0.155)

(0.157)

(0.139)

(0.135)

Latitude

$$
0.0151^{* 4}
$$

$0.0155^{* *}$

$0.0141^{* *}$

$0.0168 * *$

$-0.000197$

$-0.000984$

0.000144

$-0.00135$

(0.00666)

(0.00651) (0.00721)

(0.00417)

(0.00387)

(0.00411)

(0.00423)

Longitude

$0.0140 * * * \quad 0.0139 * * * \quad 0.0148 * * *$

$0.0139 * * *$

$0.00441^{* * *}$

$0.00431^{* * *} \quad 0.00394 * * *$

$0.00404 * * *$ (0.00231)

Days since

the first

confirmed

case

$$
\begin{array}{llll}
0.000893 & -0.00102 & -0.000495 & -0.00233
\end{array}
$$

0.00603

$0.00800^{* *}$

0.00667*

$0.00763^{*}$

$(0.00726)$

(0.00714)

(0.00754)

(0.00730)

(0.00385)

(0.00394)

(0.00398)

(0.00399)

Confirmed

Cases 1M

pop $(\log )$

$0.878 * * *$

$0.902 * * *$

$0.885 * * *$

$0.910 * * *$ 


\begin{tabular}{lcccccccc} 
& & & & & $(0.0524)$ & $(0.0554)$ & $(0.0525)$ & $(0.0584)$ \\
Constant & $-5.040 * *$ & $-4.420^{*}$ & $-4.419 *$ & $-4.032 *$ & $-5.844 * *$ & $-6.457 * * *$ & $-6.137 * * *$ & $-6.346 * * *$ \\
& $(2.427)$ & $(2.381)$ & $(2.492)$ & $(2.396)$ & $(1.364)$ & $(1.414)$ & $(1.388)$ & $(1.431)$ \\
\hline R-squared & 0.613 & 0.617 & 0.616 & 0.630 & 0.897 & 0.900 & 0.899 & 0.901 \\
AIC & 498.7693 & 499.2131 & 501.4029 & 498.123 & 311.6392 & 308.5403 & 311.8046 & 310.7135 \\
BIC & 525.4349 & 528.8416 & 528.1312 & 527.8212 & 341.2677 & 341.1316 & 341.5028 & 343.3814 \\
\hline Observations & 143 & 143 & 144 & 144 & 143 & 143 & 144 & 144 \\
\hline
\end{tabular}

Robust standard errors in

parentheses

$* * * \mathrm{p}<0.01$,

$* * \mathrm{p}<0.05, *$

$\mathrm{p}<0.1$ 
Appendix 3: Determinants of COVID-19 Cases (OLS)

\begin{tabular}{|c|c|c|c|c|}
\hline & (9) & (10) & (11) & (12) \\
\hline & OLS & OLS & OLS & OLS \\
\hline VARIABLES & $\begin{array}{l}\text { Confirmed per } 1 \mathrm{M} \\
\qquad(\log )\end{array}$ & $\begin{array}{l}\text { Confirmed per } 1 \mathrm{M} \\
\qquad(\log )\end{array}$ & $\begin{array}{l}\text { Confirmed per } 1 \mathrm{M} \\
\qquad(\log )\end{array}$ & $\begin{array}{c}\text { Confirmed per } 1 \mathrm{M} \\
(\log )\end{array}$ \\
\hline \multirow[t]{2}{*}{ Polity2 } & 0.0219 & 0.0129 & & \\
\hline & $(0.0324)$ & $(0.0341)$ & & \\
\hline \multirow[t]{2}{*}{ MPI } & & & -0.884 & -0.128 \\
\hline & & & $(0.692)$ & $(0.752)$ \\
\hline \multirow[t]{2}{*}{ Government Effectiveness } & $-0.426^{*}$ & -0.0499 & -0.230 & 0.257 \\
\hline & $(0.249)$ & $(0.276)$ & $(0.276)$ & $(0.288)$ \\
\hline \multicolumn{5}{|l|}{ Polity $2 \times$ Government } \\
\hline \multirow[t]{2}{*}{ Effectiveness } & & $-0.0752 * * *$ & & \\
\hline & & $(0.0252)$ & & \\
\hline \multicolumn{5}{|l|}{ MPI $\times$ Government } \\
\hline \multirow[t]{2}{*}{ Effectiveness } & & & & $-1.586^{* * * *}$ \\
\hline & & & & $(0.388)$ \\
\hline \multirow[t]{2}{*}{ GDP per capita (log) } & $1.057 * * *$ & $1.027 * * *$ & $0.995 * * *$ & $1.035 * * *$ \\
\hline & $(0.171)$ & $(0.169)$ & $(0.157)$ & $(0.150)$ \\
\hline \multirow[t]{2}{*}{ Population Density (log) } & 0.104 & 0.0600 & 0.0851 & 0.0525 \\
\hline & $(0.0838)$ & $(0.0822)$ & $(0.0793)$ & $(0.0766)$ \\
\hline \multirow[t]{2}{*}{ Age 65 and above (ratio) } & 0.0315 & 0.278 & 0.344 & 0.343 \\
\hline & $(0.283)$ & $(0.302)$ & $(0.239)$ & $(0.226)$ \\
\hline \multirow[t]{2}{*}{ Latitude } & $0.0180 * * *$ & $0.0189 * * *$ & $0.0157 * * *$ & $0.0198 * * *$ \\
\hline & $(0.00533)$ & $(0.00531)$ & $(0.00505)$ & $(0.00519)$ \\
\hline \multirow[t]{2}{*}{ Longitude } & $-0.0124 * * *$ & $-0.0121 * * *$ & $-0.0140 * * *$ & $-0.0128 * * *$ \\
\hline & $(0.00207)$ & $(0.00207)$ & $(0.00223)$ & $(0.00228)$ \\
\hline \multicolumn{5}{|l|}{ Days since the first } \\
\hline \multirow[t]{2}{*}{ confirmed case } & -0.00526 & -0.00961 & -0.00822 & -0.0106 \\
\hline & $(0.00838)$ & $(0.00797)$ & $(0.00910)$ & $(0.00851)$ \\
\hline \multirow[t]{2}{*}{ Constant } & 0.182 & 1.647 & 1.604 & 2.056 \\
\hline & (2.635) & $(2.512)$ & $(2.757)$ & $(2.590)$ \\
\hline R-squared & 0.617 & 0.640 & 0.621 & 0.652 \\
\hline AIC & 520.3403 & 513.1445 & 522.2325 & 511.328 \\
\hline BIC & 547.2542 & 543.0489 & 549.2074 & 541.3001 \\
\hline
\end{tabular}


Robust standard errors in parentheses

$* * * \mathrm{p}<0.01, * * \mathrm{p}<0.05, *$

$\mathrm{p}<0.1$ 